The University of Maine

\title{
DigitalCommons@UMaine
}

Maine-Syracuse Longitudinal Papers

Maine-Syracuse Longitudinal Study

1990

\section{Primary hyperepinephrinemia in patients without pheochromocytoma}

David H. P. Streeten

Gunnar H. Anderson

Mitchell Lebowitz

Philip J. Speller

Follow this and additional works at: https:// digitalcommons.library.umaine.edu/

longitudinal_papers

\section{Repository Citation}

Streeten, David H. P.; Anderson, Gunnar H.; Lebowitz, Mitchell; and Speller, Philip J., "Primary hyperepinephrinemia in patients without pheochromocytoma" (1990). Maine-Syracuse Longitudinal Papers. 64.

https://digitalcommons.library.umaine.edu/longitudinal_papers / 64 
Both Babesia and Borrelia burgdorferi are transmitted by the Ixodide tick. It is not surprising then that cases of simultaneous infection with these parasites have been reported and that patients with Lyme disease sometimes have elevated Babesia titers. ${ }^{5}$ It is interesting to speculate that our patient may have acquired Babesia when she contracted Lyme disease in 1985, and remained asymptomatic for several years.

The presence of a spleen has been believed to confer a mild, or asymptomatic, clinical course in human babesiosis. ${ }^{3}$ Our patient developed sudden respiratory failure despite radiologic evidence of a spleen. The clinical manifestations of babesiosis in patients with a spleen may therefore be more severe than previously recognized in patients. To our knowledge, only one case of babesiosis associated with adult respiratory distress syndrome has been reported in a patient with an intact spleen. ${ }^{6}$ That patient died after sequential treatment with quinine and chloroquine for 3 and 2 days, respectively.

Although data on the treatment of babesiosis are limited by the rare occurrence of this disease, the treatment of choice appears to include exchange transfusion ${ }^{7,8}$ and/or clindamycin and oral quinin $e^{9,10}$ based on clinical observations and experimental data. In this case, the combination of exchange transfusion, clindamycin, and quinine completely eliminated Babesia from the blood within several days, without subsequent relapse.
We believe that prompt treatment with this combination of therapies was a major factor in our patient's survival and would be beneficial in similar life-threatening Babesia infections.

We thank the Centers for Disease Control, Atlanta, $\mathrm{Ga}$, for supporting the diagnosis of Babesia.

\section{References}

1. Dammin GJ, Spielman A, Benach JL, Piesman J. The rising incidence of clinical Babesia mictori infection. Hum Pathol. 1981;12:398-400.

2. Ruebush TK II, Juranek DD, Chishold ES, Snow MT, Healy GR, Sulzer AJ. Human babesiosis on Nantucket Island: evidence for self-limited and subclinical infections. N Engl J Med. 1977;297:825-827.

3. Rosner F, Zarrabi HM, Benach JL, Habicht JL. Babesiosis in splenectomized adults. Am J Med. 1984;76:696-701.

4. Steketee RW, Eckman MR, Burgess EC, et al. Babesiosis in Wisconsin. JAMA. 1985;253:2675-2678.

5. Benach JL, Coleman JL, Habicht GS, MacDonald A, Grunwaldt E, Giron J. Serologic evidence for Lyme disease and babesiosis. J Infect Dis. 1985; 152:473-477.

6. Gordon S, Cordon RA, Mazdzer EJ, Valigorsky JM, Blagg NA, Barnes SJ. Adult respiratory distress syndrome in babesiosis. Chest. 1984;86:633-634.

7. Jacoby GA, Hunt JV, Kosinski KS, et al. Treatment of transfusiontransmitted babesiosis by exchange transfusion. N Engl J Med. 1980;303:1098 1100.

8. Cahill KM, Benach JL, Reich LM. Red cell exchange: treatment of babesiosis in a splenectomized patient. Transfusion. 1981;21:193-198.

9. Wittner M, Rowin KS, Tanowitz HB, et al. Successful chemotherapy of transfusion babesiosis. Ann Intern Med. 1982;96:601-604.

10. Rowen KS, Tanowitz HB, Wittner M. Therapy of experimental babesiosis. Ann Intern Med. 1982;97:556-558.

\section{Primary Hyperepinephrinemia in Patients Without Pheochromocytoma}

David H. P. Streeten, MB, DPhil, FRCP; Gunnar H. Anderson, Jr, MD; Mitchell Lebowitz, MD; Philip J. Speller, MD

\begin{abstract}
- Clinical features of epinephrine release led to the finding of spontaneously elevated plasma epinephrine concentrations in five patients, in four of whom plasma norepinephrine concentratlons were normal. Adrenal medullary hyperplasia was suspected in one patient, whose first cousin had multiple endocrine neoplasla type lla, and In two others, all of whom have experienced rellef from symptoms during propranolol or atenolol administration. The other two patients had unilateral adrenal cysts, with negative metalodobenzylguanidine scans and no hlstologlcal evidence of pheochromocytoma, but complete rellef of symptoms by exclalon of the cysts. In one patient, Cushing's syndrome and associated hypertension, diabetes, and Ischemic finger-tlp ulceration all disappeared after surgery. It is concluded that spontaneous hyperepinephrinemlc manifestations can be relleved by $\beta$-blockers or, when an adrenal mass is present, by unilateral adrenalectomy even when the metalodobenzylguanidine test reault la negative.
\end{abstract}

(Arch Intern Med. 1990;150:1528-1533)

\footnotetext{
Accepted for publication August 29, 1989

From the Department of Medicine, State University of New York Health Science Center and Crouse Irving-Memorial Hospital, Syracuse.

Reprint requests to Department of Medicine, College of Medicine, SUNY Health Science Center, 750 E Adams St, Syracuse, NY 13210 (Dr Streeten).
}

Plasma catecholamine concentrations are elevated and the symptoms of hyperepinephrinemia are present in most patients with pheochromocytoma and in many individuals as a relatively nonspecific response to the "stress" of severe illness. ${ }^{1,2}$ In most of these circumstances, plasma concentrations of both norepinephrine and epinephrine are raised. ${ }^{1}$ Isolated or predominant elevation of plasma epinephrine concentration is a characteristic physiologic response to hypoglycemia, ${ }^{3}$ caffeine intake, ${ }^{4}$ cigarette smoking, ${ }^{5}$ and some emotional stimuli $^{1}$ and occurs in occasional patients with pheochromocytoma. ${ }^{6}$ There are theoretical reasons for postulating that excessive epinephrine release might play an important role in the pathogenesis of essential hypertension, ${ }^{7,8}$ but there is no convincing evidence of hyperepinephrinemia in more than extremely rare patients with hypertension. In the absence of severe, stressful illnesses, hypoglycemia, and excessive use of caffeine, tobacco, and perhaps other drugs, the combination of clinical features and confirmatory evidence of elevated plasma epinephrine concentrations on repeated occasions strongly suggests the presence of a pheochromocytoma or of adrenal medullary hyperplasia, as is seen in members of families with multiple endocrine neoplasia type II.,10 We describe herein five patients in whom recurrent hyperepinephrinemia associated with symptoms that were improved or 


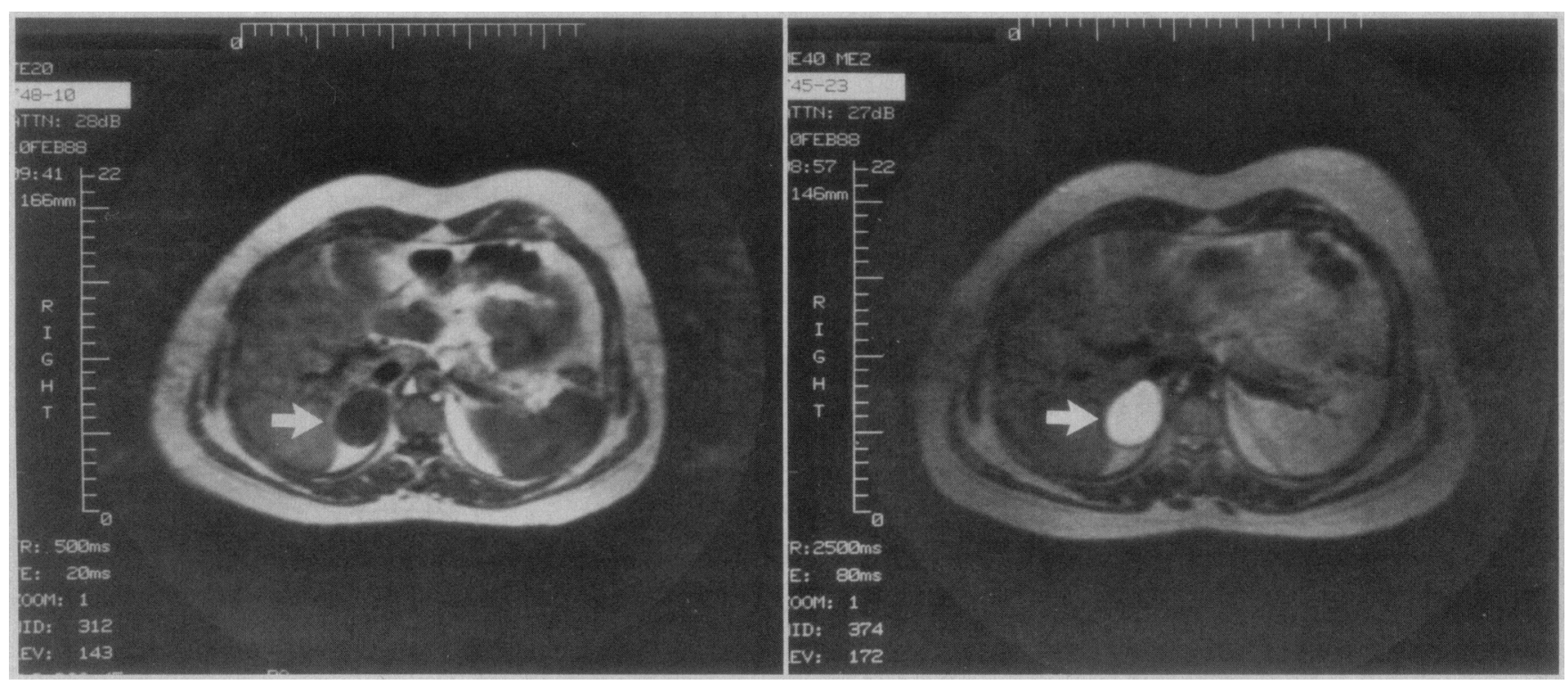

Fig 1. - Left, Magnetic resonance image of the right adrenal mass (arrow) in patient 2. Right, The opacity evident in the $\mathrm{T}_{2}$-weighted image indicates that the mass (arrow) is a cyst.

relieved by $\beta$-blocking drugs was associated with a unilateral adrenal cyst (two patients) or presumed adrenal medullary hyperplasia (three patients), with excellent responses to unilateral adrenalectomy and $\beta$-blocker therapy, respectively.

\section{REPORT OF CASES}

CASE 1.-A 45-year-old woman presented in 1981 with lightheadedness, tremors, and episodes of tachycardia that occurred almost daily, most frequently 3 to 4 hours after lunch or during the night, awakening her from sleep. During one of these nocturnal episodes she went to the emergency room of a neighboring hospital and was found to have sinus tachycardia ( 140 beats per minute). During the attacks she often experienced pain in the right costovertebral angle, and at the end of the episodes she frequently developed carpal spasms, which were witnessed during her first admission to our university hospital.

She had positive Chvostek and Trousseau signs and thyromegaly, with normal levels of serum calcium $(2.15 \mathrm{mmol} / \mathrm{L})$, thyroxine $(107 \mathrm{nmol} / \mathrm{L})$, and thyrotropin $(3.2 \mathrm{mU} / \mathrm{L})$. Serum electrolyte levels were normal (sodium, $141 \mathrm{mmol} / \mathrm{L}$; potassium, $3.5 \mathrm{mmol} / \mathrm{L}$; chloride, $105 \mathrm{mmol} / \mathrm{L}$; and bicarbonate, $28 \mathrm{mmol} / \mathrm{L}$ ), except that the serum potassium level fell during two spontaneous exacerbations of tachycardia and tremors to 3.2 and $2.9 \mathrm{mmol} / \mathrm{L}$, associated with tetany. An intravenous infusion of epinephrine at $2 \mu \mathrm{g} / \mathrm{min}$ reproduced the patient's spontaneous symptoms, lowered the serum potassium level from 3.8 to $2.9 \mathrm{mmol} / \mathrm{L}$ in 30 minutes, and induced a carpal spasm. All symptoms were relieved within 3 minutes by propranolol hydrochloride, $1 \mathrm{mg}$ given intravenously.

An intravenous injection of histamine phosphate, $40 \mu \mathrm{g}$, increased the blood pressure from $114 / 78$ to $150 / 93 \mathrm{~mm} \mathrm{Hg}$ and the heart rate from 72 to 120 beats per minute. Plasma total catecholamine level rose 2 minutes after the histamine injection, from 1.08 to $2.47 \mathrm{nmol} / \mathrm{L}$ (measured on this occasion by radioenzymatic assay).

In response to an insulin tolerance test (using regular human insulin, $0.15 \mathrm{U} / \mathrm{kg}$ ) on three occasions between 1982 and 1985, plasma epinephrine level ${ }^{11}$ rose to an extent indistinguishable from the response seen in nine normal subjects (data not shown). Computed tomographic (CT) scans of the adrenal glands and pelvis were normal.

The observations made in 1981 suggested hyperepinephrinemia resulting from adrenal medullary hyperplasia, and this speculation was supported by the subsequent discovery and treatment of multi- ple endocrine neoplasia type II in a first cousin in 1983, since there is evidence that adrenal medullary hyperplasia frequently occurs in some families with multiple endocrine neoplasia type II., ${ }^{9,10}$

The patient was given propranolol hydrochloride in a dose of 30 to $100 \mathrm{mg} / \mathrm{d}$ from 1981 until December 1986, when she was found to have bronchial asthma. Propranolol therapy was discontinued, and after having been totally asymptomatic for $5^{1 / 2}$ years with propranolol therapy, she continued to be free of symptoms without $\beta$-blocker therapy until March 1989, when she began to experience recurrence of exhaustion and episodes of tachycardia and right lumbar pain. These symptoms again responded well to a small dose of propranolol hydrochloride ( $10 \mathrm{mg}$ three times daily) without recurrence of her respiratory symptoms. Computed tomographic scans of the adrenal glands were normal in 1981, 1982, 1983, 1985, and 1989.

CASE 2. - A 42-year-old woman developed tenderness in an enlarged thyroid gland in 1977 in association with euthyroidism. Remission of her symptoms followed prednisone therapy for what was considered to be granulomatous thyroiditis. She remained asymptomatic with suppressive doses of levothyroxine sodium $(0.1 \mathrm{mg} / \mathrm{d})$ until 1983 , when she began to complain of fatigue and palpitations associated with spontaneous bouts of supraventricular tachycardia and normal serum thyroxine $(125 \mathrm{nmol} / \mathrm{L})$ and thyrotropin $(1.0 \mathrm{mU} / \mathrm{L})$ concentrations.

The patient was given propranolol hydrochloride, $20 \mathrm{mg}$ four times daily. This appeared to produce some improvement but failed to prevent the occurrence, with gradually increasing frequency between 1983 and 1988 , of bouts of severe palpitations, shakiness, anxiety, nervousness, "weakness," excessive sweating, and pallor associated with a feeling of warmth and backaches in the right costovertebral angle. Phenoxybenzamine hydrochloride in a dose of $10 \mathrm{mg}$ orally was followed by severe facial flushing and fatigue and could not be tolerated. There was no clinical evidence of Cushing's syndrome, and the plasma cortisol concentration was normal and fell normally (to $40 \mathrm{nmol} / \mathrm{L}$ ) at $8 \mathrm{AM}$ after $1.0 \mathrm{mg}$ of dexamethasone was given at midnight. Serum thyroxine and thyrotropin levels continued to be normal, but plasma epinephrine level was found to be intermittently elevated to $538 \mathrm{pmol} / \mathrm{L}$.

A CT scan in 1987 revealed a mass in the area of the right adrenal gland, which appeared to be cystic, with peripheral calcification. A magnetic resonance image confirmed the cystic nature of the lesion, which measured $4.5 \times 3.5 \times 3.0 \mathrm{~cm}$ (Fig 1). Plasma catecholamine levels showed normal or slightly elevated plasma epinephrine and 
consistently normal norepinephrine concentrations, but adrenal vein catheterization revealed concentrations of epinephrine and norepinephrine of 906 and $76 \mathrm{nmol} / \mathrm{L}$, respectively, in the right adrenal vein blood, with concentrations no higher than those in the inferior vena cava ( 0.87 and $2.45 \mathrm{nmol} / \mathrm{L}$, respectively) in the left adrenal vein blood. A right adrenal phlebogram showed a circumferential vein encircling the cyst (Fig 2).

The frequency of the patient's bouts of feeling hot and sweaty, with palpitations, tremulousness, abdominal cramps, and right costovertebral angle backaches, increased to three or four per month and were frightening to the patient. It became evident that many of these episodes occurred between 1 and 3 AM, awakening her from sleep. The attacks were unimproved by chlorpromazine, $25 \mathrm{mg}$ orally. Although the result of a metaiodobenzylguanidine (MIBG) test ${ }^{12}$ was negative, the evidence that the epinephrine was derived from the adrenal cyst led to the decision to excise the cyst on Sept 27, 1988. It weighed $14.5 \mathrm{~g}$ and contained a clear fluid with high concentrations of epinephrine $(83.9 \mathrm{nmol} / \mathrm{L})$, norepinephrine $(18.7 \mathrm{nmol} / \mathrm{L})$, cortisol $(2318 \mathrm{nmol} / \mathrm{L})$, and aldosterone $(20 \mathrm{nmol} / \mathrm{L})$.

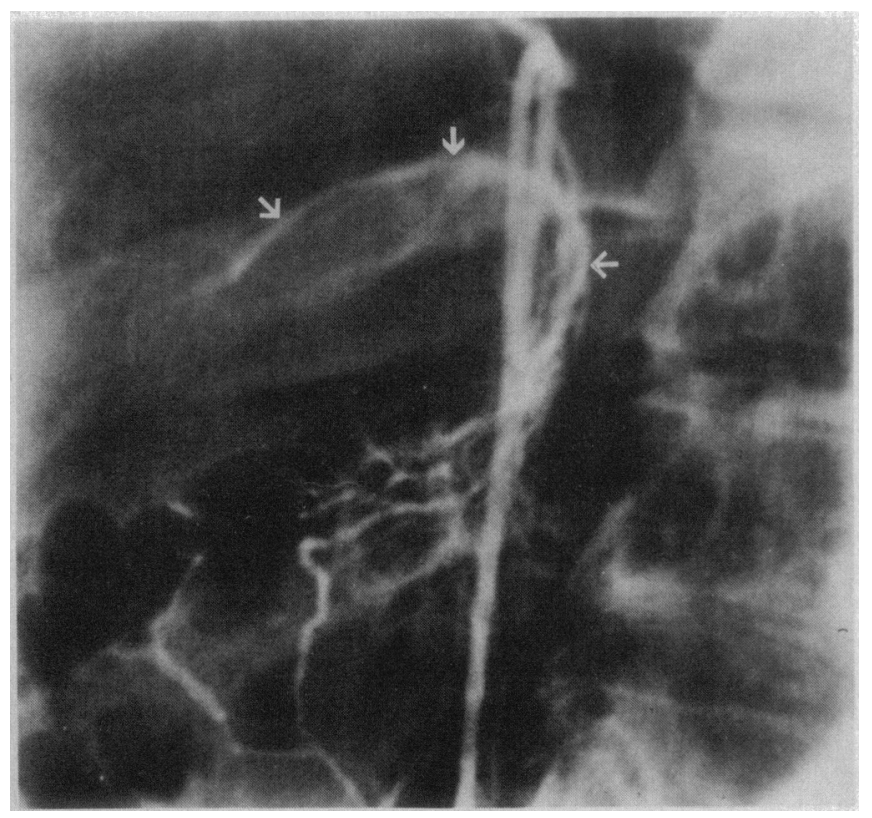

Fig 2. - Right adrenal phlebogram showing a circumferential vein (arrows) encircling the adrenal cyst in patient 2.
In the 13 months since the surgery, plasma epinephrine concentrations have been normal and the patient has been asymptomatic.

CASE 3. - A 56-year-old woman underwent subtotal gastrectomy for recurrent peptic ulceration in 1975. A year later she was found to have diabetes mellitus, type II, which was treated with diet and isophane insulin, $24 \mathrm{U}$ daily. Early in 1986 she developed painful, blue discoloration of her fingertips with subsequent persistent ulceration of the second and third fingertips of the left hand. In the fall of 1986 she was found to have anemia, and she began to notice deterioration of diabetic control, with frequent spells of documented hypoglycemia, a $13.5-\mathrm{kg}$ weight loss, progressive weakness, and episodes of palpitations, tremors, nervousness, a feeling of warmth with excessive sweating, lightheadedness, pallor, and several ecchymoses.

On admission to the Crouse Irving-Memorial Hospital, Syracuse, NY, the patient was found to have systolic hypertension with a wide pulse pressure (blood pressure varying from $146 / 68$ to $190 / 90 \mathrm{~mm} \mathrm{Hg}$ ) without significant orthostatic change, but with tachycardia (100 beats per minute recumbent, 128 beats per minute standing). She was emaciated (height, $162 \mathrm{~cm}$; weight, $45 \mathrm{~kg}$ ), with diminished muscle mass, weakness, and thinned, sweaty skin with several ecchymoses and ulcerated fingertips (second and third) on the left hand. There was no evident excess of supraclavicular or cervicodorsal fat. No peripheral edema and no cutaneous striae were present.

Laboratory studies disclosed anemia (hemoglobin level, $105 \mathrm{~g} / \mathrm{L}$ ), neutrophil leukocytosis $\left(11.1 \times 10^{9} / \mathrm{L}\right.$, with 0.81 segmented and 0.06 band cells), hypokalemia (serum potassium level, $2.7 \mathrm{mmol} / \mathrm{L}$; sodium level, $143 \mathrm{mmol} / \mathrm{L}$; chloride level, $89 \mathrm{mmol} / \mathrm{L}$; and bicarbonate level, $>40 \mathrm{mmol} / \mathrm{L}$ ), negative results for cryoglobulin, and no evidence of vasculitis on a skin biopsy specimen. There was clear-cut evidence of hypercortisolism, daily urinary 17 -hydroxycorticosteroid excretion being $18.4 \mu \mathrm{mol} / \mathrm{mmol}$ of creatinine (normal, 0.6 to $2.0 \mu \mathrm{mol} / \mathrm{mmol}$ of creatinine) before and $32.1 \mu \mathrm{mol} / \mathrm{mmol}$ of creatinine on the second day of administration of dexamethasone ( $0.5 \mathrm{mg}$ every 6 hours). There was also elevation of plasma cortisol and catecholamine concentrations (Table 1). Urinary excretion of catecholamines was measured on 3 days and found to be as follows: norepinephrine, $39.8,40.4$, and $42.0 \mu \mathrm{mol} / \mathrm{d}$ (normal, 3.3 to $42 \mu \mathrm{mol} / \mathrm{d}$ ); epinephrine, 64, 93, and $100 \mu \mathrm{mol} / \mathrm{d}$ (normal, 1.6 to $40 \mu \mathrm{mol} / \mathrm{d}$ ); and dopamine, 238, 235, and $330 \mu \mathrm{mol} / \mathrm{d}$ (normal, 49 to $284 \mu \mathrm{mol} / \mathrm{d}$ ). Thus, while the excretion of norepinephrine and dopamine was close to the upper limits of the respective reference ranges, epinephrine excretion was consistently excessive.

A CT scan (Fig 3) demonstrated a right adrenal mass that measured $2.4 \times 1.5 \mathrm{~cm}$. Adrenal vein catheterization was unsuccessful on the right side but showed that the left adrenal gland was secreting cortisol and epinephrine: plasma cortisol level in the left adrenal vein was $6070 \mathrm{nmol} / \mathrm{L}$, and in the inferior vena cava, $1076 \mathrm{nmol} / \mathrm{L}$; plasma epinephrine level in the left adrenal vein was $921 \mathrm{nmol} / \mathrm{L}$, and in the

\begin{tabular}{|c|c|c|c|c|c|}
\hline \multirow[b]{2}{*}{ Therapy } & \multicolumn{2}{|c|}{$\begin{array}{c}\text { Plasma Cortisol, } \\
\mathrm{nmol} / \mathrm{L}\end{array}$} & \multirow{2}{*}{$\begin{array}{l}\text { Plasma } \\
\text { Epinephrine, } \\
\text { pmol/L }\end{array}$} & \multirow{2}{*}{$\begin{array}{l}\text { Plasma } \\
\text { Norepinephrine } \\
\text { nmol/L }\end{array}$} & \multirow{2}{*}{$\begin{array}{c}\text { Plasma } \\
\text { Dopamine, } \\
\text { nmol/L }\end{array}$} \\
\hline & 8 AM & 4 PM & & & \\
\hline None & 1214 & 828 & 3832 & 4.09 & 4.03 \\
\hline None & $\ldots$ & $\ldots$ & 2636 & 2.65 & 3.96 \\
\hline None & & & 1845 & 4.89 & 2.87 \\
\hline Dexamethasone, $0.5 \mathrm{mg}$ every $6 \mathrm{~h}$, 2nd d & 2353 & 1504 & $\ldots$ & $\ldots$ & $\ldots$ \\
\hline After 2nd d & 2985 & & $\ldots$ & $\ldots$ & $\ldots$ \\
\hline Dexamethasone, $2 \mathrm{mg}$ every $6 \mathrm{~h}, 2$ nd $d$ & 2400 & 1308 & & & $\ldots$ \\
\hline $18 \mathrm{~d}$ after adrenalectomy & 172 & $\ldots$ & 169 & 1.48 & 0 \\
\hline 3 mo after adrenalectomy & 102 & $\ldots$ & 82 & 2.68 (standing) & 0 \\
\hline 8 mo after adrenalectomy & 320 & $\ldots$ & 311 & 2.89 (standing) & 0 \\
\hline 16 mo after adrenalectomy & 372 & $\ldots$ & 217 & 2.18 (standing) & 0 \\
\hline \multicolumn{6}{|l|}{ Normal (no treatment) } \\
\hline Recumbent & $140-770$ & $\ldots$ & $110-490$ & $0.49-1.640$ & 0 \\
\hline Standing & $\ldots$ & & $110-490$ & $1.40-4.64$ & 0 \\
\hline
\end{tabular}


inferior vena cava, $1.57 \mathrm{nmol} / \mathrm{L}$. An MIBG scan did not confirm the presence of a pheochromocytoma, since no significant accumulation of the radionuclide was seen in the adrenal glands.

On January 20,1987, a cystic right adrenal gland was removed and found to show no histologic evidence of pheochromocytoma. The patient's condition improved gradually but dramatically after the surgery. She regained muscle mass, and her weight rose in the subsequent 2 years to $48 \mathrm{~kg}$. Blood pressure fell toward normal levels (152/80 $\mathrm{mm} \mathrm{Hg}$ recumbent, 148/88 $\mathrm{mm} \mathrm{Hg}$ standing) with normal heart rates ( 76 beats per minute recumbent, 84 beats per minute standing). The diabetes disappeared, and the plasma glucose level has been consistently normal since surgery. The fingertip ulceration healed, strength has returned to normal, and all symptoms have disappeared during treatment with estrogen only (for the patient's osteoporosis). Plasma cortisol and catecholamine concentrations have been normal. The patient has returned to full-time work on a factory assembly line without loss of time during the past 24 months.

CASE 4.-A 69-year-old woman presented with recent onset of hypertension associated with severe pounding headaches that would often awaken her at night. She complained also of palpitations, tremors, and lightheadedness, followed occasionally by syncope. Apart from the hypertension with rather widely variable blood pressures (from $132 / 76$ to $188 / 108 \mathrm{~mm} \mathrm{Hg}$ ) and some obesity, the physical

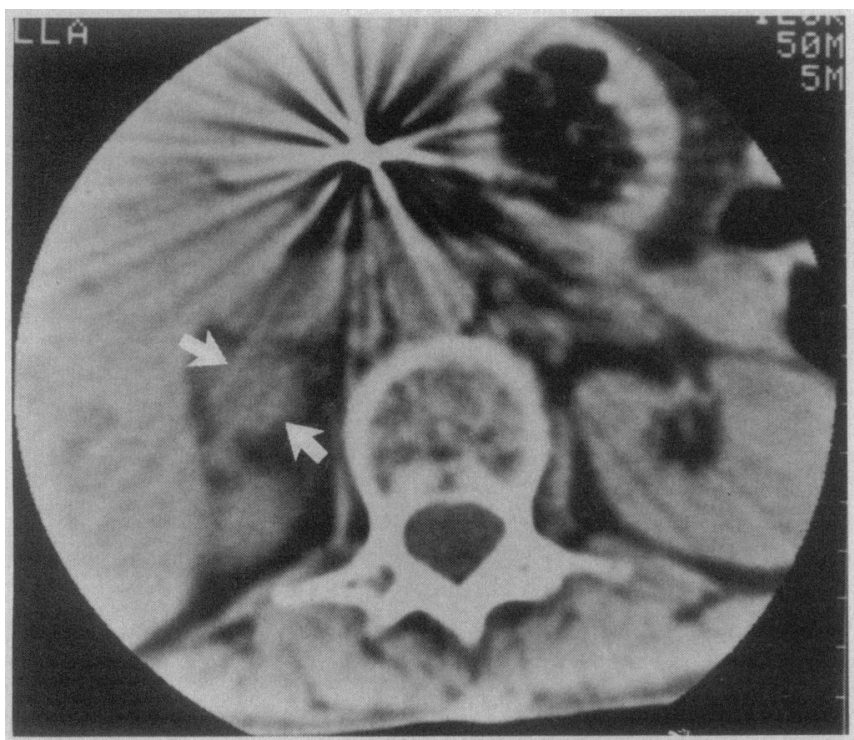

Fig 3. - Computed tomographic scan showing the mass (arrows) in the left adrenal gland in patient 3 , which was shown by ultrasound to be cystic. examination was unrevealing. Blood pressure was found, when nor$\mathrm{mal}$, to rise after administration of histamine phosphate ( $40 \mu \mathrm{g}$ intravenously) from $132 / 76$ to $152 / 102 \mathrm{~mm} \mathrm{Hg}$ and, when spontaneously elevated, to fall from $240 / 106$ to $124 / 72 \mathrm{~mm} \mathrm{Hg}$ after administration of phentolamine mesylate ( $5 \mathrm{mg}$ intravenously). Plasma catecholamine determination showed normal or mildly elevated levels of norepinephrine but almost invariably raised concentrations of epinephrine (502 to $2554 \mathrm{pmol} / \mathrm{L}$ ) in seven determinations. Since the CT scan failed to confirm the strong suspicion that a pheochromocytoma was present, the patient was treated with propranolol hydrochloride, $20 \mathrm{mg}$ three times daily. Her blood pressure fell and she was asymptomatic with this treatment.

CASE 5. - A 42-year-old, obese woman had had brawny edema in the legs since 1964, probably due to lymphatic obstruction (lymphedema precox). In 1983, she began to complain of night sweats (usually between 2 and $3 \mathrm{AM}$ ), associated with heat intolerance, tremors, lightheadedness, and headaches. She was found to have diabetes mellitus, type II, which responded well to a low-carbohydrate, low-energy diet, without improving her symptoms. Apart from the brawny edema and generalized obesity (height, $152 \mathrm{~cm}$; weight, $106.5 \mathrm{~kg}$ ), the results of physical examination were unrevealing. Plasma epinephrine levels were found to be very high (Table 2), but a CT scan of the abdomen and an MIBG test were negative. Symptoms were strikingly reduced by treatment with atenolol, $50 \mathrm{mg} / \mathrm{d}$, for 6 months.

\section{RESULTS}

All of the patients were seen because of symptoms suggestive of hyperepinephrinemia: palpitations, nervousness, "weakness," excessive sweating, pounding headaches, tremors, and feeling hot but with cutaneous pallor. All patients were found on more than one occasion to have elevated plasma epinephrine concentrations, between 491 and $2636 \mathrm{pmol} / \mathrm{L}$, measured by an electrometric method after separation by high-performance liquid chromatography. ${ }^{11}$ Computed tomographic scans revealed enlargement of one adrenal gland in two of the patients and normal adrenal glands in the other three patients. The MIBG scans of the adrenal glands ${ }^{12}$ were negative in the four patients who were studied with this procedure.

\section{Clinical and Laboratory Findings}

Most of the symptoms in the five patients were consistent with the persistent or episodic presence of hyperepinephrinemia (Table 3). However, the predominant or presenting features were quite variable. Plasma epinephrine concentration was elevated above $491 \mathrm{pmol} / \mathrm{L}$ in all five patients, while plasma norepinephrine level was normal except in patient 3

\begin{tabular}{|c|c|c|c|c|c|c|c|c|}
\hline \multirow[b]{2}{*}{ Patient } & \multicolumn{2}{|c|}{$\begin{array}{l}\text { Plasma } \\
\text { Norepinephrine, } \\
\text { nmol// }\end{array}$} & \multicolumn{2}{|c|}{$\begin{array}{l}\text { Plasma } \\
\text { Epinephrine, } \\
\text { pmol/L }\end{array}$} & \multirow{2}{*}{$\begin{array}{l}\text { Urinary } \\
\text { VMA, } \\
\text { emol/d }\end{array}$} & \multirow{2}{*}{$\begin{array}{c}\text { CT of } \\
\text { Adrenals }\end{array}$} & \multirow{2}{*}{$\begin{array}{c}\text { MIBG } \\
\text { Test }\end{array}$} & \multirow{2}{*}{$\begin{array}{l}\text { Evidence of } \\
\text { Other Disorders }\end{array}$} \\
\hline & Lying & Standing & Lying & Standing & & & & \\
\hline 1 & 0.469 & 2.042 & 932 & 5104 & 45.4 & Normal & Negative & $\begin{array}{l}\text { MEN type IIA } \\
\text { in 1st cousin }\end{array}$ \\
\hline $\begin{array}{l}2 \\
3\end{array}$ & $\begin{array}{l}0.655 \\
2.653\end{array}$ & $\begin{array}{l}2.271 \\
4.612\end{array}$ & $\begin{array}{l}186-535 \\
2636\end{array}$ & $\begin{array}{r}235 \\
2374\end{array}$ & $\ddot{59.5}$ & $\begin{array}{l}\text { Adrenal mass } \\
\text { Adrenal mass }\end{array}$ & $\begin{array}{l}\text { Negative } \\
\text { Negative }\end{array}$ & $\begin{array}{l}\text { Diabetes mellitus } \\
\text { Cushing's syndrome } \\
\text { (severe) }\end{array}$ \\
\hline $\begin{array}{c}4 \\
5 \\
\text { Normal } \\
\text { ranges }\end{array}$ & $\begin{array}{l}1.15 \\
1.20 \\
0.490-1.637\end{array}$ & $\begin{array}{l}3.766 \\
1.676 \\
1.365-4.64\end{array}$ & $\begin{array}{l}2347 \\
2118 \\
110-490\end{array}$ & $\begin{array}{l}2554 \\
650 \\
110-490\end{array}$ & $\begin{array}{c}\cdots \\
15-45\end{array}$ & $\begin{array}{l}\text { Normal } \\
\text { Normal } \\
\text { Normal }\end{array}$ & $\begin{array}{l}\text { Negative } \\
\text { Negative }\end{array}$ & $\begin{array}{l}\text { Hypertension } \\
\text { Diabetes mellitus } \\
\text { Negative }\end{array}$ \\
\hline
\end{tabular}

*VMA indicates vanillyImandelic acid; CT, computed tomography; MIBG, metaiodobenzylguanidine; and MEN, multiple endocrine neoplasia. 


\begin{tabular}{|c|c|c|c|c|c|c|c|c|c|c|c|c|}
\hline \multirow[b]{2}{*}{$\begin{array}{l}\text { Patlent } \\
\text { Age, y }\end{array}$} & \multirow[b]{2}{*}{$\begin{array}{l}\text { Palpita- } \\
\text { tions }\end{array}$} & \multirow[b]{2}{*}{$\begin{array}{c}\text { Nervous- } \\
\text { ness }\end{array}$} & \multirow[b]{2}{*}{ "Weakness" } & \multirow[b]{2}{*}{$\begin{array}{l}\text { Excess } \\
\text { Sweating }\end{array}$} & \multirow[b]{2}{*}{$\begin{array}{l}\text { Head- } \\
\text { aches }\end{array}$} & \multirow[b]{2}{*}{$\begin{array}{c}\text { Light- } \\
\text { headedness }\end{array}$} & \multirow[b]{2}{*}{ Tremors } & \multirow[b]{2}{*}{$\begin{array}{l}\text { Feeling } \\
\text { Hot }\end{array}$} & \multirow[b]{2}{*}{ Pallor } & \multicolumn{2}{|c|}{ Recumbent } & \multirow[b]{2}{*}{$\begin{array}{l}\text { Orthostatic } \\
\text { Hypotension }\end{array}$} \\
\hline & & & & & & & & & & $\begin{array}{l}\text { Blood } \\
\text { Pressure, } \\
\text { mm Hg }\end{array}$ & $\begin{array}{c}\text { Pulse, } \\
\text { Beate/min }\end{array}$ & \\
\hline $1 / 45$ & + & + & + & + & 0 & + & + & + & + & $100 / 64$ & 68 & + \\
\hline $2 / 42$ & + & + & + & + & 0 & 0 & 0 & + & + & $134 / 98$ & 96 & 0 \\
\hline $3 / 56$ & + & + & + & + & 0 & + & + & + & + & $146 / 78$ & 100 & 0 \\
\hline $4 / 69$ & + & + & 0 & 0 & + & + & 0 & 0 & 0 & $132 / 74$ & 92 & + \\
\hline $5 / 42$ & + & 0 & + & + & 0 & + & 0 & + & + & $166 / 82$ & 76 & \pm \\
\hline
\end{tabular}

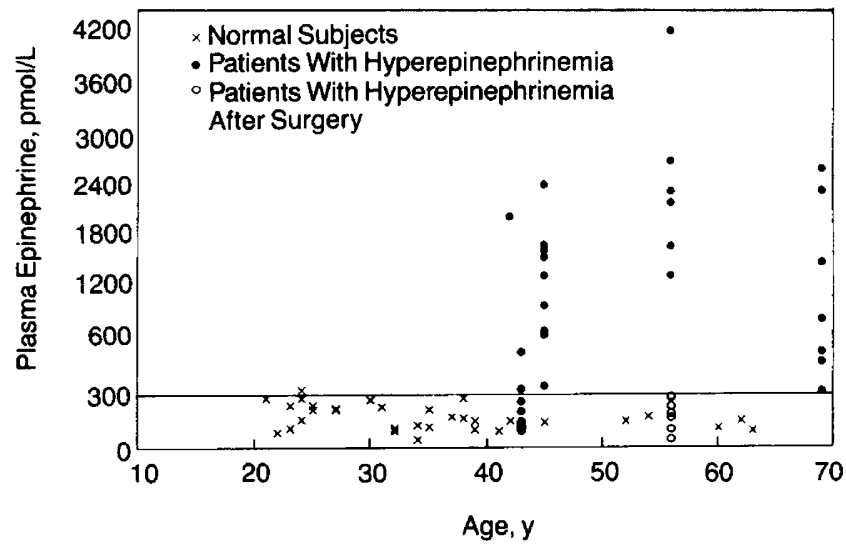

Fig 4. - Plasma epinephrine concentrations in the five patients compared with those of normal subjects of various ages. The open circles show plasma epinephrine concentrations in the two patients with adrenal cysts after surgical excision of the cysts. The horizontal tine delineates the upper limit of the normal range of plasma epinephrine concentrations.

(Table 2). The plasma epinephrine concentrations in the five patients are compared with those in 33 healthy volunteers in Fig 4.

\section{Histologic Examination of the Adrenal Cysts}

There was a thick, fibrous tissue lining of the cysts removed from patients 2 and 3 , in which smooth muscle cells were present. Adrenal cortical and medullary cells were present in both cyst walls, with cortical hyperplasia in patient 3 . The medullary cells were active, with prominent nuclei, and showed the usual staining with neuron-specific enolase. No evidence of pheochromocytoma was found in the adrenal tissue removed from either patient.

\section{COMMENT}

The patients described in this report all had intermittent, frequently nocturnal, or continuous elevation of plasma epinephrine concentration, with the symptoms expected from these findings and relief of the symptoms by unilateral adrenalectomy in the two patients with unilateral adrenal cysts or therapy with $\beta$-adrenergic blocking drugs. Although the relief of symptoms by $\beta$-adrenergic blockade is not conclusive evidence of excessive epinephrine release, it is certainly consistent with this possibility. Elevations of plasma epinephrine concentration of the magnitude seen in these patients can occur during severe emotional or physical stresses, during hypoglycemia, or in the presence of a pheochromocytoma; none of these conditions was found to be present. ${ }^{1}$
Although the evidence relating to the stimulation of epinephrine release in these patients is fragmentary, one patient (patient 1) showed a normal epinephrine response to insulininduced hypoglycemia. One of the two patients with adrenal cysts and all three patients who were thought to have adrenal medullary hyperplasia experienced spontaneous episodes suggesting acute hyperepinephrinemia, which were stimulated by epinephrine infusion in one of them. In all of the patients these episodes awakened the individuals frequently in the early hours of the morning and were, therefore, presumably not induced by any type of "stress." Whether adrenal medullary secretion plays a physiologic role in maintaining euglycemia in the absence of food intake during sleep, and might have been excessive in these patients, is not known. There is evidence that epinephrine release plays an important role in the restoration of euglycemia after insulin-induced hypoglycemia in diabetic patients, but this role of epinephrine is crucial only in glucagon deficiency ${ }^{18,14}$ Since hyperepinephrinemia was frequently shown to be present in the immediate postprandial state in these patients, however, it is clear that hypoglycemia is not the only trigger to excessive epinephrine release in these patients.

The diagnosis of hyperepinephrinemia was suspected on clinical grounds since the symptoms of hyperepinephrinemia were present in the absence of evident hypoglycemic or other stresses or pheochromocytoma. Measurements of plasma epinephrine concentration or urinary epinephrine excretion established the diagnosis. Pheochromocytomas associated with excessive epinephrine release can usually, but not always, be excluded by a normal CT sean of the abdomen and pelvis. The presence of an adrenal mass in two patients made it necessary to perform MIBG scans. Although the MIBG test is not very sensitive and may be negative in patients with small pheochromocytomas, it is usually positive in lesions as large as those found by CT scan in patients 2 and 3 . When the sonogram suggested an adrenal cyst in two patients and MIBG scans did not show excessive concentrations of the radionuclide within the cysts, we were hesitant to proceed with surgery. However, the strong evidence of severe hypercortisolism in patient 3 that was unsuppressible even with dexamethasone in a dose of $2 \mathrm{mg}$ given every 6 hours led us to recommend surgery in this patient. In retrospect, this was a fortunate decision, since the patient, who had been extremely ill and considered preterminal by several of her physicians, was restored by adrenalectomy to an active, productive, asymptomatic life. The decision to remove the adrenal cyst in patient 2 was more difficult and was resisted for many months until it became evident that her attacks of hyperepinephrinemia were becoming more frequent and more severe despite the administration of propranolol in the maximal dose that she 
could tolerate while continuing to work. The finding of extremely high levels of plasma epinephrine in the vein draining the cyst and not in the contralateral adrenal vein indicated that the epinephrine excess was probably coming from the adrenal cyst.

Histologic examination in our pathology department and in a national consulting laboratory gave no evidence of a pheochromocytoma in either adrenal cyst. Whether the medullary cells in the wall of the cyst were remnants of a previous pheochromocytoma that had undergone necrosis could not be decided. While the mass of the adrenal medullary cells was insufficient to provide a positive MIBG test, it was clearly sufficient in both patients to cause severe and, in one instance, incapacitating ill health.

It was of interest to observe the occurrence of severe hypokalemia in two of our five patients. Epinephrine administration is known to induce hypokalemia rapidly by enhancing cellular uptake of potassium through a $\beta_{2}$-receptor-mediated effect. ${ }^{15-17}$ This is probably the mechanism of hypokalemia after myocardial infarction. ${ }^{18}$ The occurrence of hypokalemia in our patients and its usual absence in patients with pheochromocytoma ${ }^{18}$ might result from the more episodic release of epinephrine in the patients described herein or from the usual absence of concomitant, excessive norepinephrine release, which is characteristic of most patients with pheochromocytoma.

This study was supported by research grant RO1 AG03055 from the National Heart, Lung, and Blood Institute, Bethesda, Md, and Clinical Research Center grant RR229 from the Division of Research Facilities and Resources, US Public Health Service.

\section{References}

1. Cryer PE. Physiology and pathophysiology of the human sympathoadrenal neuroendocrine system. $N$ Engl J Med. 1980;303:436-444.

2. Christensen NJ, Videbaek J. Plasma catecholamines and carbohydrate metabolism in patients with acute myocardial infarction. J Clin Invest.

\section{$1974 ; 54 ; 278-286$.}

3. Clutter W, Bier D, Shah S, Cryer PE. Epinephrine: plasma metabolic clearance rates and physiologic thresholds for metabolic and hemodynamic actions in man. J Clin Invest. 1980;66:94-101.

4. Robertson D, Frölich JC, Carr RK, et al. Effects of caffeine on plasms renein activity, catecholamines and blood pressure. $N$ Engl $J$ Med. 1978;298:181-186.

5. Cryer PE, Haymond MW, Santiago JV, Shah SD. Norepinephrine and epinephrine release and adrenergic mediation of smoking-associated hemodynamic and metabolic events. N Engl J Med. 1976;295:573-577.

6. Hamrin B. Sustained hypotension and shock due to an adrenaline-gecreting pheochromocytoms. Lancet. 1962;2:123-124.

7. Brown MJ, Macquin I. Is adrenaline the cause of essential hypertension? Lancet. 1981;2:1079-1082.

8. Blankestijn PJ, Man in't Veld AJ, Tulen J, et al. Support for adrenalinehypertension hypothesis: 18 hour pressor effect after 6 hours adrenaline infusion. Lancet. 1988;2:1386-1389.

9. Carney JA, Sizemore GW, Tyce GM. Bilateral adrenal medullary hyperplasia in multiple endocrine neoplasia, type 2: the precursor of bilateral pheochromocytoma. Mayo Clin Proc. 1975;50:3-10.

10. DeLellis RA, Wolfe HJ, Gagel RF, et al. Adrenal medullary hyperplasia: a morphometric analysis in patients with familial medullary thyroid carcinoma. Am J Puthol. 1976;83:177-196.

11. Watson E. Liquid chromatography with electrochemical detection for plasma norepinephrine and epinephrine. Life Sci. 1981;28:493-497.

12. Sisson JC, Frager MS, Valk TW, et al. Scintigraphic localization of pheochromocytoma. N Engl J Med. 1981;305:12-17.

13. Rizza RA, Cryer PE, Gerich JE. Role of glucagon, catecholamines, and growth hormone in human glucose counter-regulation: effects of somatostatin and combined $\alpha$ - and $\beta$-adrenergic blockade on plasma glucose recovery and glucose flux rates after insulin-induced hypoglycemia. $J$ Clin Invest. $1979 ; 64: 62-71$.

14. Gerich J, Davis J, Lorenzi $M$, et al. Hormonal mechanisms of recovery from insulin-induced hypoglycemia in man. Am J Physiol. 1979;236:E380 E385.

15. Bethune DW, McKay R. Paradoxical changes in serum potassium during cardiopulmonary bypass in association with non-cardioselective beta blockade. Lancet. 1978;1:380-381.

16. Petch MC, McKay R, Bethune DW. The effect of beta -adrenergic $^{-}$ blockade on serum potassium and glucose levels during open heart surgery. Eur Heart J. 1981;2:123-126.

17. Brown MJ, Brown DC, Murphy MB. Hypokalemia from beta - -receptor stimulation by circulating epinephrine. $N$ Engl J Med. 1983;309:1414-1419.

18. Donnelly T, Gray H, Simpson E, Rodger JC. Serum potassium in acute myocardial infarction. Scot Med J. 1980;25:176.

19. Manger WM, Gifford RW Jr. Pheochromocytoma. New York, NY: Springer-Verlag; 1977:282-295. 